\title{
Evaluating MERS-CoV Entry Pathways
}

\section{Enya Qing, Michael P. Hantak, Gautami G. Galpalli, and Tom Gallagher}

\begin{abstract}
Middle East respiratory syndrome coronavirus (MERS-CoV) is an emerging zoonotic pathogen with a broad host range. The extent of MERS-CoV in nature can be traced to its adaptable cell entry steps. The virus can bind host-cell carbohydrates as well as proteinaceous receptors. Following receptor interaction, the virus can utilize diverse host proteases for cleavage activation of virus-host cell membrane fusion and subsequent genome delivery. The fusion and genome delivery steps can be completed at variable times and places, either at or near cell surfaces or deep within endosomes. Investigators focusing on the CoVs have developed several methodologies that effectively distinguish these different cell entry pathways. Here we describe these methods, highlighting virus-cell entry factors, entry inhibitors, and viral determinants that specify the cell entry routes. While the specific methods described herein were utilized to reveal MERS-CoV entry pathways, they are equally suited for other CoVs, as well as other protease-dependent viral species.
\end{abstract}

Key words Middle East respiratory syndrome (MERS), Coronavirus (CoV), Protease, Pseudovirus, Spike (S), Viral entry, Endosome, Virus concentration, Virus purification, Protease inhibitor, HR2 peptide, IFITM3, TMPRSS2, Transfection

\section{Introduction}

Middle East respiratory syndrome coronavirus (MERS-CoV) is endemic in bats, and also in dromedary camels, and can be transmitted zoonotically from camels to humans [1-6]. The virus was discovered in humans in 2012, and since then there has been over 2,000 laboratory-confirmed cases worldwide, with $35 \%$ of infected humans suffering fatal outcomes [7-9]. Although MERS-CoV zoonotic and human-to-human transmission rates have declined due to general awareness and improved hospital practices, there are continued possibilities for epidemics, and there is a need for preventive vaccines and therapeutic antivirals. Mechanistic insights into human MERS-CoV entry will promote vaccine and antiviral drug developments.

MERS-CoV, like all other coronaviruses, exists as enveloped extracellular particles with protruding spike (S) proteins. Infection is initiated through viral $S$ protein binding to host cell receptors. 
Subsequent proteolytic cleavage of cell-bound $S$ proteins triggers $S$ protein-mediated coalescence (fusion) of viral and cell membranes. The triggering process involves a series of currently obscure $S$ protein conformational changes, from "pre-fusion" metastable states to "extended fusion intermediates" to "post-fusion" collapsed states that exist after virus and cell membranes have coalesced and viral mRNA genomes have dispensed into the host cell cytoplasm $[10,11]$. These events depend on cellular proteases, and as one may expect, the availability of particular proteases immediately following receptor engagement is a rate-limiting step in $\mathrm{CoV}$ entry.

Cellular proteases accumulate in distinct subcellular locations on the endocytic CoV entry pathway: serine proteases such as trypsin and elastase are extracellular; the type II transmembrane serine proteases (TTSPs) are anchored into plasma membranes; and the cysteine-type cathepsin proteases are enriched in endosomes $[12,13]$. For several $\mathrm{CoV}$ infections, not all of these proteases are required; however, it is possible that each has distinct potential to activate fusion such that a productive infection ensues. There is evidence that particular CoVs have "preferred" in vivo entry routes (e.g., MERS-CoV and 229E-CoV prefer plasma membrane entry, while some MHV-CoVs prefer endosome entry [14-19], (see Fig. 1). Knowledge of these preferred routes, and their relation to virus-induced disease, is necessary to identify virus variants that might have high transmissibility and disease potential, and to recognize the host factors that might be targeted therapeutically such that infections are suppressed at the cell entry stage.

Here we provide protocols to dissect CoV entry pathways. These include procedures for pseudovirus production, particle purification and concentration, as well as specific assays to differentiate CoV entry pathways. While the protocols are set for characterizing MERS-CoV entry, they can be readily adjusted to evaluate other $\mathrm{CoV}$ and other protease-dependent virus entry events.

\section{Materials}

\subsection{Particle Production}

1. $150 \mathrm{~mm}$ Tissue culture dishes.

2. HEK-293T cells.

3. 293T cell media: Dulbecco's Modified Eagle Media (DMEM) with L-glut, $4.5 \mathrm{~g} / 1$ glucose and $100 \mathrm{mM}$ sodium pyruvate, additional supplements include $10 \%$ fetal bovine serum, $10 \mathrm{mM}$ HEPES, $0.1 \mathrm{mM}$ nonessential amino acids, $100 \mathrm{U} / \mathrm{ml}$ penicillin $\mathrm{G}$, and $100 \mu \mathrm{g} / \mathrm{ml}$ streptomycin.

4. Transfection media: DMEM with L-glut, $4.5 \mathrm{~g} / 1$ glucose and $100 \mathrm{mM}$ sodium pyruvate, and 10\% fetal bovine serum. 


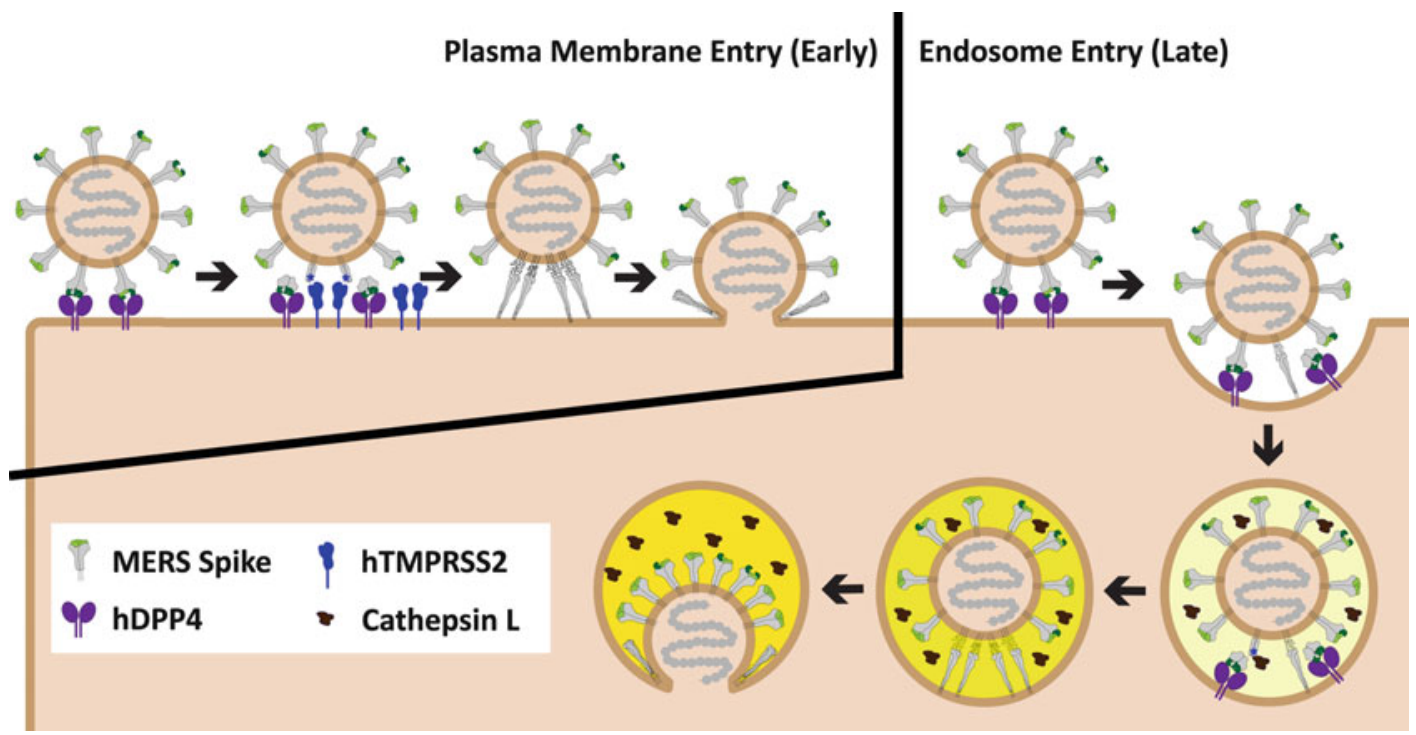

Fig. 1 MERS-CoV enters host either at or near the plasma membrane or in the endosomes. The MERS-CoV spike (S) proteins (gray) engage human DiPeptidyl Peptidase 4 (hDPP4, purple) via their receptor-binding domains (green). Receptor engagement exposes protease cleavage sites (blue stars) on S proteins. If cell surface proteases such as hTMPRSS2 (blue) are present, S proteins are cleaved and viral fusion occurs at or near the plasma membrane. If hTMPRSS2 or similar cell-surface proteases are not present, then MERS-CoV is endocytosed, and can be triggered by endosomal proteases such as cathepsin $L$ (brown) to complete viral entry

2.2 Particle

Purification and

Concentration

\subsection{Characterizing} Viral Entry Pathways
5. Serum-free media: DMEM with L-glut, $4.5 \mathrm{~g} / \mathrm{l}$ glucose and $100 \mathrm{mM}$ sodium pyruvate, additional supplements include $10 \mathrm{mM}$ HEPES, $0.1 \mathrm{mM}$ nonessential amino acids, $100 \mathrm{U} / \mathrm{ml}$ penicillin $\mathrm{G}$, and $100 \mu \mathrm{g} / \mathrm{ml}$ streptomycin.

6. Polyethylenimine (PEI) at $1 \mathrm{mg} / \mathrm{ml}$ dissolved in $\mathrm{ddH} 2 \mathrm{O}$.

7. OptiMEM reduced serum medium.

8. Expression plasmids for MERS-CoV-spike.

9. Expression plasmid for HIV core-Fluc (pNL4.3HIVluc).

10. Transducing particle: VSV $\Delta$ G-Fluc pseudotyped with Junin virus (JUNV) GP.

1. Centrifuge: Eppendorf 5810 or equivalent.

2. Ultracentrifuge: Beckman Coulter's or equivalent. SW28 swinging-bucket rotor, buckets, and Ultra-Clear tubes.

3. Falcon 15 and $50 \mathrm{ml}$ conical centrifuge tubes.

4. Sucrose solution: $20 \%$ sucrose $(\mathrm{w} / \mathrm{v})$ in serum-free media.

1. Falcon 6-well and 96-well cell culture plates.

2. 5x Cell Culture Lysis Reagent (CCLR): $125 \mathrm{mM}$ Tris- $\mathrm{HCl}$ $\mathrm{pH}$ 7.8, $10 \mathrm{mM}$ DTT, $10 \mathrm{mM}$ 1,2-diaminocyclohexane-N,N, $\mathrm{N}^{\prime}, \mathrm{N}^{\prime}$-tetraacetic acid, 50\% glycerol, 5\% Triton X-100. 
3. Firefly luciferase substrate: $1 \mathrm{mM}$ D-luciferin, $3 \mathrm{mM}$ ATP, $15 \mathrm{mM} \mathrm{MgSO} 4 \cdot \mathrm{H} 2 \mathrm{O}, 30 \mathrm{mM}$ HEPES [pH 7.8].

4. Protease inhibitor cocktail: $200 \mu \mathrm{M}$ Camostat, $20 \mu \mathrm{M}$ proprotein convertase inhibitor, $20 \mu \mathrm{M}$ E64D in serum-free media.

5. Vehicle control: DMSO in serum-free media at equivalent levels to the protease inhibitor cocktail.

6. CoV fusion antagonists: $\mathrm{CoV}$ species-matching HR2 peptides.

7. Expression plasmids for: hTMPRSS2, hCD9, hIFITM3.

\section{Methods}

\subsection{VSV-Based \\ Pseudovirus \\ Production (see \\ Note 1)}

Carry out all incubations at $37{ }^{\circ} \mathrm{C}$ with $5 \% \mathrm{CO}_{2}$ unless otherwise specified.

1. Plate enough 293 T cells $\left(5 \times 10^{6}\right)$ in $20 \mathrm{ml}$ into a $15 \mathrm{~cm}$ dish to reach $80 \%$ confluency on the next day.

2. On the following day, make transfection mixture by adding $20 \mu \mathrm{g}$ of MERS-CoV-spike plasmid (see Note 2) and $110 \mu \mathrm{l}$ of PEI into $2 \mathrm{ml}$ of OptiMEM. Incubate the mixture in the dark for $15 \mathrm{~min}$ at room temperature.

3. Replace existing media with $20 \mathrm{ml}$ of transfection media (pre-warmed to $37^{\circ} \mathrm{C}$, see Note 3). Add transfection mixture dropwise onto the cells. Incubate the cells for $6-8 \mathrm{~h}$ (see Note 4).

4. Replace transfection media with $20 \mathrm{ml}$ of $293 \mathrm{~T}$ cell media and incubate overnight.

5. Dilute $100 \times$ transducing particle (VSV $\Delta$ G-Fluc pseudotyped with Junin virus (JUNV) GP, see Note 5) into $15 \mathrm{ml}$ of pre-warmed serum-free media, which is then used to replace existing media on the transfected cells. Incubate cells for $2 \mathrm{~h}$.

6. Remove supernatant, rinse cells with $10 \mathrm{ml}$ of pre-warmed serum-free media three times, then add back $13 \mathrm{ml}$ of pre-warmed $293 \mathrm{~T}$ cell media. Incubate cells overnight.

7. Collect supernatant (first collection) with a $15 \mathrm{ml}$ Falcon tube, add back $13 \mathrm{ml}$ of pre-warmed $293 \mathrm{~T}$ cell media, and incubate cells overnight (see Note 6).

8. Spin supernatant at $300 \times g$ for $10 \mathrm{~min}$ at $4{ }^{\circ} \mathrm{C}$.

9. Transfer supernatant into a fresh tube and spin at $3000 \times g$ for 10 min at $4{ }^{\circ} \mathrm{C}$. Discard pellet.

10. Transfer supernatant into a fresh tube and freeze it at $-80^{\circ} \mathrm{C}$. 
3.2 HIV-Based Pseudovirus Production
3.3 Particle

Purification and Concentration
11. On the following day, repeat steps 7-10 (second collection).

12. On the final day, collect supernatant (third collection), discard cells, repeat steps 8-10.

1. Plate enough 293 T cells $\left(5 \times 10^{6}\right)$ in $20 \mathrm{ml}$ into a $15 \mathrm{~cm}$ dish to reach $80 \%$ confluency on the next day.

2. On the following day, make transfection mixture by adding $10 \mu \mathrm{g}$ of MERS-CoV-spike plasmid, $10 \mu \mathrm{g}$ of HIV core-Flucexpressing plasmid, and $110 \mu \mathrm{l}$ of PEI into $2 \mathrm{ml}$ of OptiMEM. Incubate the mixture in the dark for $15 \mathrm{~min}$ at room temperature.

3. Replace existing media with $20 \mathrm{ml}$ of transfection media (pre-warmed to $37{ }^{\circ} \mathrm{C}$ ). Add transfection mixture dropwise onto the cells. Incubate the cells for $6-8 \mathrm{~h}$.

4. Replace transfection media with $20 \mathrm{ml}$ of $293 \mathrm{~T}$ cell media and incubate overnight.

5. Remove supernatant, and add back $13 \mathrm{ml}$ of pre-warmed $293 \mathrm{~T}$ cell media. Incubate cells overnight.

6. Collect supernatant (first collection) with a $15 \mathrm{ml}$ Falcon tube, add back $13 \mathrm{ml}$ of pre-warmed $293 \mathrm{~T}$ cell media, and incubate cells overnight.

7. Spin supernatant at $300 \times g$ for $10 \mathrm{~min}$ at $4{ }^{\circ} \mathrm{C}$.

8. Transfer supernatant into a fresh tube and spin at $3000 \times \mathfrak{g}$ for $10 \mathrm{~min}$ at $4{ }^{\circ} \mathrm{C}$. Discard pellet.

9. Transfer supernatant into a fresh tube and freeze it at $-80^{\circ} \mathrm{C}$.

10. On the following day, repeat steps 6-9 (second collection).

11. On the final day, collect supernatant (third collection), discard cells, repeat steps 7-9.

We noted that pseudoviruses lose their transduction capabilities (up to $90 \%$ !) upon exposure to the high g-forces $(\sim 100,000 \times g)$ commonly used in traditional viral concentration methods. Therefore, we adopted a low-speed viral concentration and purification protocol that achieves viral concentration without compromising viral transduction capabilities.

1. Thaw and pool collected pseudovirus-containing supernatants (see Subheadings 3.1 or 3.2).

2. Transfer $32 \mathrm{ml}$ of the pooled supernatant into a SW28 UltraClear tube.

3. Use a $3 \mathrm{ml}$ syringe with needle to add a cushion of $3 \mathrm{ml}$ of $20 \%$ sucrose to the bottom of the tube. Eject from syringe slowly to avoid sucrose mixing with the sample. After the placement of the cushion, gently add the remaining sample $(\sim 3 \mathrm{ml})$ into the 


\subsection{Characterizing CoV Entry Pathways}

3.4.1 Characterizing CoV Entry Kinetics Using Protease Inhibitor Cocktails (see Note 9) tube. If there is still space, add serum-free media to the brim of the Ultra-Clear tube.

4. Load the Ultra-Clear tube into a SW28 bucket, and spin at $6500 \mathrm{rpm}(5591 \times g)$ for $18 \mathrm{~h}$ at $4{ }^{\circ} \mathrm{C}$.

5. After the spin, carefully take out the Ultra-Clear tube, and remove all the supernatant without disturbing the pellet at the bottom center (may be invisible). Quickly add back $\sim 350 \mathrm{ml}$ of serum-free media, and gently resuspend the pellet with a $1 \mathrm{ml}$ pipette ( see Note 8). Aliquot and store the fully resuspended sample (now $100 \times$ and purified) at $-80{ }^{\circ} \mathrm{C}$ for future use.

Subsequent to receptor engagement, $\mathrm{CoV}$ spikes require proteolytic cleavage to trigger membrane fusion. Two classes of cellular proteases have been identified to trigger $\mathrm{CoV}$ fusions: Serine proteases that are either secreted or expressed on the plasma membrane $[14,17]$, and cysteine proteases that resides in the endosome $[18,19]$. Therefore, the utilization of specific proteases by a given $\mathrm{CoV}$ also dictates its site of entry. We utilize several assays to differentiate the preferred site of entry for wild-type (WT) and mutant MERS spikes, the efficacies of entry inhibitors, and the identification of pro- or antiviral host factors.

The CoV site of entry is correlated with entry kinetics, with viral entry at the plasma membrane being "early," and entry through endosomes "late," in relation to the different virus trafficking times prior to membrane fusion [15-17]. Together with the knowledge that $\mathrm{CoV}$ entry requires proteolysis, we utilize a time-course assay to characterize $\mathrm{CoV}$ entry kinetics, where protease inhibitors are added at various time points to arrest future entry, allowing readouts for infection within short inoculation time windows.

1. Plate sufficient permissive cells into a 96-well plate, $60 \mu \mathrm{l}$ per well, to reach $95 \%$ confluency on the next day.

2. On the following day, add $40 \mu \mathrm{l}$ of MERS spike-bearing viral particles (Subheadings 3.1 or 3.2) onto cells. Incubate the plate at $4{ }^{\circ} \mathrm{C}$ for $1 \mathrm{~h}$ to allow viral binding.

3 . After $1 \mathrm{~h}$, remove unbound particles by aspirating the supernatant (see Note 10). Add back $50 \mu \mathrm{l}$ of fresh media. Incubate the plate at $37^{\circ} \mathrm{C}$.

4. At various time intervals $(0,5,10,15,20,25,30,35,40,45$, $60 \mathrm{~min}$, and so on, see Note 11 ), add $50 \mu$ l of protease inhibitor cocktail to the cells. At time interval of $0 \mathrm{~min}$, also have a condition where $50 \mu \mathrm{l}$ of vehicle control (see Note 12) is added instead. Leave the drugs/vehicle on cells and incubate at $37^{\circ} \mathrm{C}$ overnight ( $18 \mathrm{~h}$ post viral inoculation). 


\subsubsection{Characterizing Entry Routes Using Specific Protease Inhibitors}

5. Remove media, add $50 \mu \mathrm{l}$ of $1 \times \operatorname{CCLR}(5 \mathrm{x}$ CCLR diluted in $\mathrm{ddH} 2 \mathrm{O})$ to lyse cells. Freeze the plate at $-80{ }^{\circ} \mathrm{C}$ for $30 \mathrm{~min}$ ( see Note 13). Thaw the plate and transfer $20 \mu$ to a white reading plate to analyze firefly luciferase activity. Normalize enzyme activity from all conditions to the vehicle control, which is set to "100\%". Plot data as "\% viral entry."

The entry assay (Subheading 3.4.1) can sensitively distinguish viruses with accelerated or delayed kinetics, but it is frequently time and reagent consuming. The assay can be simplified by an alternative where titration of a particular inhibitor is applied for a short period of time.

1. Plate sufficient permissive cells into a 96-well plate, $60 \mu \mathrm{l}$ per well, to reach $95 \%$ confluency on the next day.

2. On the following day, at $-1 \mathrm{~h}$, remove media and add $60 \mu \mathrm{l}$ of protease inhibitor or vehicle-containing serum-free media (1-1000 $\mu \mathrm{M}$ camostat to inhibit plasma membrane protease TMPRSS2, or 1-1000 $\mu \mathrm{M}$ E64D to inhibit endosomal cathepsins). Incubate cells for $1 \mathrm{~h}$ at $37^{\circ} \mathrm{C}$.

3. Add $40 \mu \mathrm{l}$ of MERS spike-bearing viral particles (Subheading 3.1 or 3.2 ) onto cells. Incubate the plate at $37^{\circ} \mathrm{C}$ for $2 \mathrm{~h}$ to allow viral entry.

4. After $2 \mathrm{~h}$, remove unbound particles by aspirating the supernatant. Rinse twice with $100 \mu \mathrm{l}$ PBS. Add back $50 \mu \mathrm{l}$ of fresh media. Incubate the plate at $37^{\circ} \mathrm{C}$ overnight $(\sim 18 \mathrm{~h}$ post viral inoculation).

5. Remove media, add $50 \mu \mathrm{l}$ of $1 \times$ CCLR to lyse cells. Freeze the plate at $-80^{\circ} \mathrm{C}$ for $30 \mathrm{~min}$. Thaw the plate and transfer $20 \mu \mathrm{l}$ to a white reading plate to analyze firefly luciferase activity. Normalize enzyme activity from all conditions to the vehicle control, which is set to " $100 \%$." Plot data as "\% viral entry."

3.4.3 Characterizing Entry Routes Using Spike Fusion Antagonists
The protocol described in Subheading 3.4.2 is flexible and can be tailored to evaluate different viral inhibitors. These include fusion inhibitors. CoV spike proteins facilitate membrane fusion by transiting from "extended fusion intermediates" to "post-fusion" conformations. This transition requires interactions between antiparallel helices termed heptad repeat region $1(\mathrm{HRl})$ and 2 (HR2) [20,2l], and can be arrested by exogenous HR2 peptides, which bind to the fusion intermediates. Typically, HR2 peptides do not enter endosomes and therefore only arrest viruses that transition into intermediate conformations extracellularly, i.e., at target cell plasma membranes. However, lipid-conjugated HR2 peptides can bind plasma membranes and endocytose, accumulating in endosomes such that they will arrest intracellular virus-cell membrane fusion. Using a modified Subheading 3.4.2, we tested the 
3.4.4 Identifying Host Factors Participating in MERS-CoV Entry efficacy of native vs. lipid-conjugated HR2 on blocking CoV endosomal entry [22].

1. Plate sufficient permissive cells into a 96-well plate, $60 \mu \mathrm{l}$ per well, to reach $95 \%$ confluency on the next day.

2. On the following day, at $-1 \mathrm{~h}$, remove media and add $60 \mu \mathrm{l}$ of native vs. lipid-conjugated HR2 peptides at $0.01-1 \mu \mathrm{M}$, or vehicle control. Incubate cells for $1 \mathrm{~h}$ at $37^{\circ} \mathrm{C}$.

3. Add $40 \mu \mathrm{l}$ of MERS spike-bearing viral particles (Subheadings 3.1 or 3.2 ) onto cells. Incubate the plate at $37^{\circ} \mathrm{C}$ for $1 \mathrm{~h}$ to allow viral entry.

4. After $1 \mathrm{~h}$, remove unbound particles by aspirating the supernatant. Rinse twice with $100 \mu \mathrm{l}$ PBS. Add back $50 \mu \mathrm{l}$ of fresh media. Incubate the plate at $37^{\circ} \mathrm{C}$ overnight $(\sim 18 \mathrm{~h}$ post viral inoculation).

5. Remove media, add $50 \mu \mathrm{l}$ of $1 x$ CCLR to lyse cells. Freeze the plate at $-80^{\circ} \mathrm{C}$ for $30 \mathrm{~min}$. Thaw the plate and transfer $20 \mu \mathrm{l}$ to a white reading plate to analyze firefly luciferase activity. Normalize enzyme activity from all conditions to the vehicle control, which is set to " $100 \%$." Plot data as "\% viral entry."

With the ability to differentiate between MERS-CoV entry at the plasma membrane and within endosomes, we and others have identified several host factors that affect viral routes of entry $[14,15,17,23,24]$. These include but are not limited to: (1) transmembrane protease serine subtype 2 (hTMPRSS2), which facilitates MERS-CoV entry at the plasma membrane. (2) tetraspanin hCD9, which ferries the MERS-CoV receptor hDPP4 into close proximity with hTMPRSS2 to potentiate MERS-CoV entry at the plasma membrane. (3) interferon-induced transmembrane protein 3 (hIFITM3), which blocks CoV endosomal entry.

1. Plate sufficient permissive cells into a 6 -well plate, $2 \mathrm{ml}$ per well, to reach $85 \%$ confluency on the next day.

2. On the following day, transfect cells with expression plasmids for vector control, hTMPRSS2, hCD9, or hIFITM3 (see Note 14):

(a) Make transfection mixture by adding $1 \mu \mathrm{g}$ of plasmid and $12 \mu \mathrm{l}$ of PEI into $200 \mu \mathrm{l}$ of OptiMEM. Incubate the mixture in the dark for $15 \mathrm{~min}$ at room temperature.

(b) Replace existing media with $2 \mathrm{ml}$ of transfection media (pre-warmed to $37^{\circ} \mathrm{C}$ ). Add transfection mixture dropwise onto the cells. Incubate the cells for $6-8 \mathrm{~h}$.

(c) Replace transfection media with $2 \mathrm{ml}$ of fresh media and incubate overnight. 
3. On the next day, plate sufficient transfected cells into a 96-well plate, $60 \mu \mathrm{l}$ per well, to reach $95 \%$ confluency on the next day.

4. Add $40 \mu \mathrm{l}$ of MERS spike-bearing viral particles (Subheadings 3.1 or 3.2 ) onto cells. Incubate the plate at $4{ }^{\circ} \mathrm{C}$ for $1 \mathrm{~h}$ to allow viral binding.

5. After $1 \mathrm{~h}$, remove unbound particles by aspirating the supernatant. Add back $50 \mu \mathrm{l}$ of fresh media. Incubate the plate at $37^{\circ} \mathrm{C}$.

6. At various time intervals $(0,5,10,15,20,25,30,35,40,45$, $60 \mathrm{~min}$, and so on), add $50 \mu \mathrm{l}$ of protease inhibitor cocktail to the cells. At time interval of $0 \mathrm{~min}$, also have a condition where $50 \mu \mathrm{l}$ of vehicle control is added instead. Leave the drugs/ vehicle on cells and incubate at $37{ }^{\circ} \mathrm{C}$ overnight $(\sim 18 \mathrm{~h}$ post viral inoculation).

7. Remove media, add $50 \mu \mathrm{l}$ of $1 \times$ CCLR $(5 \times$ CCLR diluted in $\mathrm{ddH} 2 \mathrm{O})$ to lyse cells. Freeze the plate at $-80{ }^{\circ} \mathrm{C}$ for $30 \mathrm{~min}$. Thaw the plate and transfer $20 \mu \mathrm{l}$ to a white reading plate to analyze firefly luciferase activity. Normalize enzyme activity from all conditions to the vehicle control, which is set to "100\%." Plot data as "\% viral entry."

\section{Notes}

1. The current protocol describes particle production in $15-\mathrm{cm}$ diameter plates. This protocol can be scaled up or down as long as the ratio of all components remains constant. However, for consistency and reproducibility we do not recommend producing particles in container sizes smaller than $5-\mathrm{cm}$ diameter.

2. When using PEI as a transfection reagent, use $1 \mu \mathrm{g}$ of DNA per million cells.

3. 293T cells can detach from the plate, so exert care when replacing media. Always add back media after aspiration as soon as possible to prevent cell-drying. When adding media, liquid should land on the side wall of the plate, not directly onto the cells. Always pre-warm media.

4. The DNA:PEI ratio $(1: \sim 6)$ is optimized specifically for a transfection period of $6-8 \mathrm{~h}$. If transfection is allowed to go overnight, lower the DNA:PEI ratio to $1: 3$.

5. JUNV GP-vsv $\Delta \mathrm{G}$ pseudovirus was chosen for its short half-life, which reduces the amount of inoculum JUNV GP pseudovirus contaminating the desired $\mathrm{CoV}$-spike- vsv $\Delta \mathrm{G}$.

6. This protocol maximizes pseudovirus production by taking three consecutive harvests from the producer cells (24-48, 
48-72, and 72-96 h post-transfection). Each harvest period brings similar pseudovirus yields.

7. At the indicated spin speed, the k-factor is 4556. Since the sedimentation coefficients of VSV [25] or HIV [26] pseudovirus are around 500, a 9-h spin is sufficient. The actual spin time is doubled to insure that the pseudoviruses are pelleted through the more viscous $20 \%$ sucrose cushion.

8. When resuspending pellet, set $1 \mathrm{ml}$ pipette to $200 \mu \mathrm{l}$ and pipette up and down gently to avoid bubbles. Make sure to rinse the entire bottom of the tube to maximize collection.

9. The current protocol describes viral entry into cells seeded in 96-well plates. This protocol can be scaled up as long as the ratio of all components remains constant.

10. After removing media via aspiration, return fresh media to cells as soon as possible to prevent cell drying. Aspirate and return media from a maximum of 24 wells at a time.

11. CoV entry kinetics are unique to each virus and host cell combination. In LET- 1 cells, MERS-CoV entry completes in around $1 \mathrm{~h}$. In HeLa cells, 229E-CoV entry takes 4+ hours to complete. Pilot experiments with larger time intervals (30-60 min) are recommended.

12. The vehicle control for protease inhibitors is DMSO, which is cytotoxic at high concentrations. Pilot experiments are recommended to identify nontoxic DMSO concentrations.

13. Samples can be kept at $-80{ }^{\circ} \mathrm{C}$ for up to a month before reading Fluc. To further prevent signal loss, protease inhibitor cocktail can be added to Ix CCLR before use.

14. For cell types that are killed by PEI:DNA transfection, lipidbased transfection vectors such as lipofectamine can be used instead. For cell types that are resistant to transfection, retro- or lenti-viral-based or adenovirus-based transduction systems can be used to introduce genes of interest [15].

\section{Acknowledgment}

This work is supported by NIAID grant AI060699 and by the Loyola University Chicago Center for Translational Research and Education.

\section{References}

1. Middle East respiratory syndrome coronavirus (MERS-CoV). https://www.who.int/en/ news-room/fact-sheets/detail/middle-east- respiratory-syndrome-coronavirus-(mers-cov). Accessed 4 Mar 2019

2. Sabir JSM, Lam TTY, Ahmed MMM et al (2016) Co-circulation of three camel 
coronavirus species and recombination of MERS-CoVs in Saudi Arabia. Science 351:81-84. https://doi.org/10.1126/sci ence.aac8608

3. Reusken CBEM, Haagmans BL, Müller MA et al (2013) Middle East respiratory syndrome coronavirus neutralising serum antibodies in dromedary camels: a comparative serological study. Lancet Infect Dis 13:859-866. https:// doi.org/10.1016/S1473-3099(13)70164-6

4. Haagmans BL, Al Dhahiry SHS, Reusken CBEM et al (2014) Middle East respiratory syndrome coronavirus in dromedary camels: an outbreak investigation. Lancet Infect Dis 14:140-145. https://doi.org/10.1016/ S1473-3099(13)70690-X

5. Memish ZA, Mishra N, Olival KJ et al (2013) Middle East respiratory syndrome coronavirus in bats, Saudi Arabia. Emerg Infect Dis 19:1819-1823. https://doi.org/10.3201/ eid1911.131172

6. Gilardi K, Byarugaba DK, Baric RS et al (2017) Further evidence for bats as the evolutionary source of Middle East respiratory syndrome coronavirus. MBio 8:1-13. https://doi.org/ $10.1128 /$ mbio.00373-17

7. (2019)WHO | Middle East respiratory syndrome coronavirus (MERS-CoV). In: WHO. https://www.who.int/emergencies/merscov/en/. Accessed 4 Mar 2019

8. Fouchier RAM, van Boheemen S, Osterhaus ADME et al (2012) Isolation of a novel coronavirus from a man with pneumonia in Saudi Arabia. N Engl J Med 367:1814-1820. https://doi.org/10.1056/nejmoal211721

9. Hijawi B, Abdallat M, Sayaydeh A et al (2013) Novel coronavirus infections in Jordan, April 2012: epidemiological findings from a retrospective investigation. East Mediterr Health J 19(Suppl 1):S12-S18

10. Li F (2016) Structure, function, and evolution of coronavirus spike proteins. Annu Rev Virol 3:237-261. https://doi.org/10.1146/ annurev-virology-110615-042301

11. Hulswit RJG, de Haan CAM, Bosch B-J (2016) Coronavirus spike protein and tropism changes. Adv Virus Res 96:29-57. https://doi. org/10.1016/bs.aivir.2016.08.004

12. Millet JK, Whittaker GR (2015) Host cell proteases: critical determinants of coronavirus tropism and pathogenesis. Virus Res 202:120-134. https://doi.org/10.1016/j. virusres.2014.11.021

13. Bugge TH, Antalis TM, Wu Q (2009) Type II Transmembraneserine proteases. J Biol Chem 284:23177-23181. 1074/jbc.R109.021006
14. Park J, Li K, Barlan A et al (2016) Proteolytic processing of Middle East respiratory syndrome coronavirus spikes expands virus tropism. Proc Natl Acad Sci U S A 113:12262-12267. https://doi.org/10. 1073/pnas.1608147113

15. Earnest JT, Hantak MP, Li K et al (2017) Thetetraspanin CD9 facilitates MERScoronavirus entry by scaffolding host cell receptors and proteases. PLoS Pathog 13: el006546. https://doi.org/10.1371/journal. ppat. 1006546

16. Li K, Wohlford-Lenane CL, Channappanavar $\mathrm{R}$ et al (2017) Mouse-adapted MERS coronavirus causes lethal lung disease in human DPP4 knockin mice. Proc Natl Acad Sci 114: E3119-E3128. https://doi.org/10.1073/ pnas.1619109114

17. Shirato K, Kanou K, Kawase M, Matsuyama S (2017) Clinical isolates of human coronavirus $229 \mathrm{E}$ bypass the endosome for cell entry. J Virol 91. https://doi.org/10.1128/JVI. 01387-16

18. Qiu Z, Hingley ST, Simmons G et al (2006) Endosomal proteolysis by cathepsins is necessary for murine coronavirus mouse hepatitis virus type 2 spike-mediated entry. J Virol 80:5768-5776. https://doi.org/10.1128/ JVI.00442-06

19. Matsuyama S, Taguchi F (2009) Two-step conformational changes in a coronavirus envelope glycoprotein mediated by receptor binding and proteolysis. J Virol 83:11133-11141. https://doi.org/10.1128/JVI.00959-09

20. Bosch BJ, Martina BEE, Van Der Zee R et al (2004) Severe acute respiratory syndrome coronavirus (SARS-CoV) infection inhibition using spike protein heptad repeat-derived peptides. Proc Natl Acad Sci U S A 101:8455-8460. https://doi.org/10.1073/ pnas.0400576101

21. Bosch BJ, Rossen JWA, Bartelink $\mathrm{W}$ et al (2008) Coronavirus escape from heptad repeat 2 (HR2)-derived peptide entry inhibition as a result of mutations in the HRl domain of the spike fusion protein. J Virol 82:2580-2585. https://doi.org/10.1128/JVI.02287-07

22. Park JE, Gallagher T (2017) Lipidation increases antiviral activities of coronavirus fusion-inhibiting peptides. Virology 511:9-18. https://doi.org/10.1016/j.virol. 2017.07.033

23. Wrensch F, Winkler M, Pöhlmann S (2014) IFITM proteins inhibit entry driven by the MERS-coronavirus spike protein: evidence for cholesterol-independent mechanisms. Viruses 6:3683-3698. https://doi.org/10.3390/ v6093683 
24. Zhao X, Sehgal M, Hou Z, et al (2017) Identification of residues controlling restriction versus enhancing activities of IFITM proteins on entry of human coronaviruses. J Virol 92. https://doi.org/10.1128/JVI.01535-17

25. Bradish CJ, Brooksby JB, Dillon JF (1956) Biophysical studies of the virus system of vesicular stomatitis. J Gen Microbiol 14:290-314. https://doi.org/10.1099/ 00221287-14-2-290

26. Vogt V (1997) Retroviral Virions and Genomes. Cold Spring Harbor Laboratory Press 